\title{
Carta de Goiânia
}

Nos, participantes do I Encontro Nacional de Trabalhadores Atingidos por Barragens. em Goiânia, de 19 a 21 de abril de 1989, reconhecemos a importância da geraşão de eletricidade, mas também da sua economia e conservação. Entretanto, sabemos que a atual política do setor elétrico atende a um modelo de desenvolvimento que privilegia os interesses do grande capital (construtoras, mineradoras, indústrias, fabricantes de equipamentos pesados e financiadores - nacionais e internacionais - e credores da divida externa), excluindo a classe trabalhadora do processo de decisão, planejamento e implantação dos programas do setor.

Esta política. concretizada no Plano 2010 da Eletrobrás, é elaborada no sigilo c'os altos gabinetes, sem a participaçāo da sociedade.

Os projetos do setor elétrico não geram só energia, mas uma série de efeitos perversos, tais como: inundação de milhares de hectares de terras férteis; aumento da corcentração fundiária - deslocando contra a sua vontade - milhares de familias de trabalhadores rurais e ribeirinhos e de povos indigenas: expulsão do homem do campo para as periferias das cidades; empobrecimento da populaçāo atingida; dispersão de comunidades e povoados; perda de um saber popular sobre a terra e o rio; alteração dos rios com ocorrência de doenças e contaminaçōes das águas.

Diante deste quadro exigimos do governo:

1) elaboraçāo de uma nova política para o setor elétrico com a participaçāo da classe trabalhadora:

2) que sejam imediatamente solucionados os problemas sociais e ambientais gerados pelas hidrelétricas ja construídas e que isto seja condiçāo para implantaçāo de novos projetos;

3) cumprimento dos acordos ja firmados entre os atingidos e as concessionárias do setor elétrico;

4) fim imediato dos subsídios tarifários às indústrias favorecidas pelo setor elétrico.

Reforma agrária já, sob o controle dos trahalhadores!

Demarcação das terras indigenas!

Demarcação das terras das comunidades negras remanescentes de quilombos!

Não pagamento da dívida externa!

Goiânia, 21 de abril de 1989

Central Única dos Trabalhadores - CUT

Comissäo Regional dos Atingidos por Barragens - CRAB

Comissāo Pastoral da Terra - CPT

Pólo-Sindical do Sub-Médio do Sāo Francisco (PE-BA)

Comissão Regional dos Atingidos por Barragens do rio Iguaçu - CRABI

Sindicato dos Trabalhadores Rurais de Altamira/Pará

Movimento de Apoio à Resistência Waimiri-Atroari-MAREWA

Comitê Calunga - Universidade Federal de Goiás

Comissão Pró-fndio de São Paulo - CPI/SP

Conselho Indigenista Missionário - CIMI

Centro de Apoio aos Movimentos Populares do Vale do Jequitinhonha - CAMPO

Centro de Estudos e Pesquisas do Instituto Sedes Sapienteae-SP - CEPIS

Centro Ecumênico de Documentação e Informáçāo - CEDI

Federação dos Estudantes de Agronomia do Brasil - FEAB

Movimento dos Trabalhadores Rurais Sem Terra-MST

Partido dos Trabalhadores - Secretária Agrária Nacional - PT

Sociedade de Defesa dos Direitos Humanos de Marabá - Pará - SDDH - Marabá

Instituto de Pesquisa e Planejamento Urbano e Regional - IPPUR/UFRJ;

Comissão de Atingidos pela UHE Dona Francisca

Comissão Regional dos Atingidos pelo Conplexo Hidrelétrico do Xingu - CRACOHX

Comissão Regional dos Atingidos por Barragens / Nordeste

Comissão Estadual de Atingidos por Barragens / Rondônia

Comissão do Povo na Luta contra a Barragem do Castanhão

Comunidade Kaingang de Iraf / RS

Comunidade Kaingang de Chapecozinho

Comunidade Avá-Guarani

Comunidade Pankararu 